\title{
Cheese pH, Protein Concentration, and Formation of Calcium Lactate Crystals
}

\author{
S. Agarwal, ${ }^{\star}$ J. R. Powers, ${ }^{\star}$ B. G. Swanson, ${ }^{\star}$ S. Chen,† and S. Clark ${ }^{\star 1}$ \\ *Department of Food Science and Human Nutrition, and \\ †Biological Systems Engineering, Washington State University, Pullman 99164-6376
}

\section{ABSTRACT}

The occurrence of calcium lactate crystals (CLC) in hard cheeses is a continual expense to the cheese industry, as consumers fail to purchase cheeses with this quality defect. This research investigates the effects of the protein concentration of cheese milk and the $\mathrm{pH}$ of cheese on the occurrence of CLC. Atomic absorption spectroscopy was used to determine total and soluble calcium concentrations in skim milk (SM1, 8.7\% total solids), and skim milk supplemented with nonfat dry milk (CSM1, 13.5\% total solids). Calcium, phosphorus, lactic acid, and citrate were determined in cheeses made with skim milk (SM2, 3.14\% protein), skim milk supplemented with ultrafiltered milk (CSM2, 6.80\% protein), and nonfat dry milk (CSM3, $6.80 \%$ protein). Supplementation with nonfat dry milk increased the initial total calcium in CSM1 (210 mg/100 g of milk) by $52 \%$ compared with the total calcium in SM1 (138 mg/ $100 \mathrm{~g}$ of milk). At pH 5.4, soluble calcium concentrations in CSM1 were $68 \%$ greater than soluble calcium in SM1. In cheeses made from CSM2 and CSM3, total calcium was $26 \%$ greater than in cheeses made from SM2. As the $\mathrm{pH}$ of cheeses made from SM2 decreased from 5.4 to 5.1 , the concentration of soluble calcium increased by $61.6 \%$. In cheeses made from CSM2 and CSM3, the concentrations of soluble calcium increased by 41.4 and $45.5 \%$, respectively. Calcium lactate crystals were observed in cheeses made from SM2 at and below $\mathrm{pH}$ 5.1, whereas CLC were observed in cheeses from CSM2 and CSM3 at and below $\mathrm{pH}$ 5.3. The increased presence of soluble calcium can potentially cause CLC to occur in cheese manufactured with increased concentrations of milk solids, particularly at and below $\mathrm{pH} 5.1$.

Key words: Cheddar cheese, soluble calcium, lactic acid, crystals

Received January 30, 2006.

Accepted May 26, 2006.

${ }^{1}$ Corresponding author: stephclark@wsu.edu

\section{INTRODUCTION}

Quality defects in Cheddar cheeses discourage repeat purchases by consumers. White crystals on the surface of Cheddar cheese have had a detrimental effect on sales since the 1930s (McDowall and McDowell, 1939). The problem remains a challenge and an expense to cheese manufacturers (Chou et al., 2003; Swearingen, et al., 2004; Agarwal et al., 2005; Rajbhandari and Kindstedt, 2005), because significant amounts of the Cheddar cheese manufactured in the United States form calcium lactate crystals (CLC) during aging (Johnson, 2004). The financial losses that CLC causes in the cheese industry warrant research into interventions to reduce the occurrence of CLC in hard and semihard cheeses.

Calcium lactate crystals may be attributed to a number of variables, including differences in milk composition (Pearce et al., 1973), cheese-making procedure (Dybing et al., 1986), aging temperature (Pearce et al., 1973; Dybing et al., 1988; Johnson et al., 1990b; Chou et al., 2003), and the growth of nonstarter lactic acid bacteria (NSLAB) in cheese during aging (Khalid and Marth, 1990; Somers et al., 2001; Chou et al., 2003). Certain NSLAB encourage the development of $\mathrm{D}(-)$-lactate, which is less soluble than $\mathrm{L}(+)$-lactate, thus promoting CLC formation (Chou, et al., 2003; Agarwal, et al., 2006). Temperature fluctuations during cheese aging encourage CLC (Chou et al., 2003) and both L(+)and $\mathrm{D}(-)$-lactate crystal development are stimulated by gas-flush packaging (Agarwal et al., 2005). Cleaning, sanitizing, preventing cheese milk contamination with lactate-racemizing NSLAB, maintaining consistent storage temperatures, and using vacuum packaging are encouraged to minimize the occurrence of CLC (Chou et al., 2003; Agarwal et al., 2005; Agarwal et al., 2006).

Although improved sanitation and good cheese-manufacturing practices are reducing the occurrence of $\mathrm{D}(-)$ lactate crystals in cheese, in recent years there has been an increased occurrence of $\mathrm{L}(+)$-lactate crystals in Cheddar cheese (Linke, 1958; Johnson, 2004; Swearingen et al., 2004; Agarwal et al., 2005; Rajbhandari and Kindstedt, 2005). Calcium from cheese milk and lactate from lactose fermentation are the principal com- 
ponents of CLC, or more specifically, calcium lactate pentahydrate $\left[\mathrm{Ca}\left(\mathrm{CH}_{3} \mathrm{CHOHCOO}\right)_{2} \cdot 5 \mathrm{H}_{2} \mathrm{O} ; \mathrm{McD}\right.$ owall and McDowell, 1939; Dybing et al., 1988; Kubantseva et al., 2004]. Increases in the occurrence of CLC are attributed to changes in cheese manufacturing techniques, such as use of UF, reverse osmosis, evaporated milk, or NDM to increase the total solids of cheese milk (Johnson, 2004). Calcium in milk and cheese is present in 2 forms, soluble (dissociated from CN) and colloidal or insoluble (associated with CN). The soluble form of calcium can readily combine with lactate to form calcium lactate. As the calcium lactate concentration exceeds saturation, microcrystals of calcium lactate are formed. Microcrystals can accrue in size to form macrocrystals that are visible to the human eye (Dybing et al., 1988). Large concentrations of protein in cheese milk are accompanied by high colloidal calcium and the potential for increased soluble calcium (SC) concentrations in cheese. Little previous research directly relates the protein concentration in cheese milk, SC, and the final $\mathrm{pH}$ of cheese to the formation of CLC. The objective of this study was to identify the relationship between protein concentrations in cheese milk and cheese $\mathrm{pH}$ in the formation of CLC. We hypothesized that cheeses made from cheese milk with increased protein concentrations, and having low $\mathrm{pH}$, would develop more CLC than standard cheeses. The results of this research will enable us to advise cheese manufacturers on cheesemaking techniques and sales schedules.

\section{MATERIALS AND METHODS}

Skim milk was chosen to study the effect of milk protein concentration on the total calcium (TC, sum of colloidal calcium and SC) and SC, and the formation of CLC to remove the variable of milk fat from the study.

\section{Preparation of Milk and Cheese}

Milk. Two different 1.0-kg batches of milk were prepared in replicate: skim milk (SM1; Meadow Gold Dairies, Dallas, TX), with TS of 8.7\%; and skim milk fortified with NDM (CSM1; Westfarm Foods, Seattle, WA), with TS of $13.5 \%$. Skim milk 1 and CSM1 were incubated in a covered stainless-steel vessel (Leedal Image Making Equipment, Chicago, IL) in a water bath (Isotemp 120; Fisher Scientific, Fair Lawn, NJ) at $30 \pm 0.5^{\circ} \mathrm{C}$. Starter culture Lactococcus lactis ssp. cremoris \#98 (Chr. Hansen, Milwaukee, WI) was grown to a cell density of $10^{8} \mathrm{cfu} / \mathrm{mL}$ in sterilized, internal $\mathrm{pH}$-controlled buffer media (Vivolac, Indianapolis, IN) and inoculated into $\mathrm{SM} 1$ and CSM1 at a rate of $1 \%(\mathrm{wt} / \mathrm{wt})$ at $30 \pm 0.5^{\circ} \mathrm{C}$. Skim milk 1 and CSM1 were analyzed for TC and SC using atomic absorption spectrometry (model SpectrAA
Table 1. Composition of skim milk (SM1), skim milk supplemented with NDM (CSM1), and milks used for making cheeses: skim milk (SM2), skim milk supplemented with UF milk (CSM2), and skim milk supplemented with NDM (CSM3) ${ }^{1}$

\begin{tabular}{lrll}
\hline Milk type & Total solids, $\%$ & Protein, \% & Lactose, \% \\
\hline SM1 & $8.7 \pm 0.16$ & $2.98 \pm 0.06$ & $4.68 \pm 0.12$ \\
CSM1 & $13.5 \pm 0.18$ & $5.78 \pm 0.14$ & $6.84 \pm 0.18$ \\
SM2 & $9.1 \pm 0.12$ & $3.14 \pm 0.08$ & $4.72 \pm 0.14$ \\
CSM2 & $12.7 \pm 0.08$ & $6.80 \pm 0.16$ & $4.95 \pm 0.28$ \\
CSM3 & $15.8 \pm 0.07$ & $6.84 \pm 0.03$ & $7.84 \pm 0.16$ \\
\hline
\end{tabular}

${ }^{1}$ Means of replicate \pm SD.

220; Varian Inc., Palo Alto, CA), initially and at $\mathrm{pH}$ of $6.3,5.8,5.6,5.4,5.3,5.2,5.1$, and 5.0.

Cheese. Three different batches of milk were standardized to make skim milk cheeses, based on the milk protein concentration and source of milk proteins. Skim milk cheeses were manufactured in duplicate, with each replicate made from $10.0 \mathrm{~kg}$ of milk, for a total of 6 cheeses. All batches of cheese were randomly distributed, with one batch of cheese made each day. The entire cheese-making process lasted more than $1.5 \mathrm{wk}$ and used the same base lot of skim milk. Skim milk (SM2; 9.15\% TS and 3.14\% protein), skim milk supplemented with UF milk (CSM2; 12.70\% TS and 6.8\% protein), and skim milk supplemented with NDM (CSM3; $15.8 \%$ TS and $6.8 \%$ protein) were made prior to cheese making (Table 1). Cheeses corresponding to SM2 (SMC2), CSM2 (CSMC2), and CSM3 (CSMC3) were made using standard procedures followed at the Washington State University Creamery, with slight modifications. The standardized and pasteurized cheese milk was added to a stainless-steel vessel (Leedal Image Making Equipment), which was placed inside a water bath (Isotemp 120; Fisher Scientific). Ultrafiltered milk for standardization of CSM2 was prepared by UF of skim milk (Meadow Gold Dairies), as described by Agarwal et al. (2005). The CSM3 cheese milk was prepared by slowly adding a calculated amount of NDM (Westfarm Foods) to skim milk (Meadow Gold Dairies) at room temperature in a glass beaker with continuous stirring using a magnetic stirrer. Care was taken to ensure that all the NDM was incorporated before storing CSM3 cheese milk overnight under refrigeration. Holding milk overnight allowed hydration of NDM and reduced any foam produced during incorporation of the NDM. Mesophillic starter culture, Lc. lactis ssp. cremoris \#98 (Chr. Hansen), was grown to a cell density of $10^{8} \mathrm{cfu} / \mathrm{mL}$ in sterilized, internal $\mathrm{pH}$-controlled buffer media (Vivolac) and inoculated into standardized milk at a rate of $1 \%$ (wt/wt) along with thermophillic starter culture, Streptococcus thermophilus \#STM4 (Chr. Hansen), at the rate of $0.1 \%$ (wt/wt) at $32^{\circ} \mathrm{C}$. Streptococcus thermophilus was added to achieve the low $\mathrm{pH}$ during 
cheese making needed for this experiment. Streptococcus thermophilus is used by cheese manufacturers to reduce the manufacturing time of Cheddar cheese (Feagan, 1956). Double-strength coagulator (Chy-Max; Chr. Hansen), diluted 1:40 with tap water, was used to assist coagulation of the milk. At the time of cutting with 6$\mathrm{mm}$ cutter-grid cheese knives, the $\mathrm{pH}$ of cheese whey was $6.60 \pm 0.02$. Curds were cooked by raising the temperature from 31 to $38^{\circ} \mathrm{C}$ at the rate of $1^{\circ} \mathrm{C}$ every $5 \mathrm{~min}$ over a 30 -min period. Curds and whey were stirred at $38^{\circ} \mathrm{C}$ for 45 min before draining, with whey at $\mathrm{pH} 6.20$. The cheese was cheddared and $60 \mathrm{~g}$ of cheese curd was removed from the vat at $\mathrm{pH} 5.40 \pm 0.02,5.30 \pm 0.02$, $5.20 \pm 0.02,5.10 \pm 0.02,5.00 \pm 0.02,4.90 \pm 0.02$, and $4.80 \pm 0.02$. At each point, the cheese curd was shredded in a food processor (model DLC-2011; Cuisinart, East Windsor, NJ) and mixed with salt $(2.5 \%$, wt/wt, of cheese curd) and erythromycin (5 mg/g of cheese; BP920; Fisher Scientific) to stop the growth of microorganisms. Curd shreds were then pressed in a laboratory press (Carver Laboratory Press; Fred S. Carver Inc., Summit NJ) at $4.14 \times 10^{7} \mathrm{~Pa}$ for $30 \mathrm{~min}$. The $\mathrm{pH}$ of the cheese was checked once again after pressing and adjusted with lactic acid (85\% solution; J.T.Baker, Phillipsburg, NJ) to pH $5.40 \pm 0.02,5.30 \pm 0.02,5.20 \pm 0.02$, $5.10 \pm 0.02,5.00 \pm 0.02,4.90 \pm 0.02$, and $4.80 \pm 0.02$, respectively, because the $\mathrm{pH}$ of cheese increased by a factor of 0.03 to 0.06 after pressing (Table 2 ). The cheese was reshredded to enable a homogeneous mixture of lactic acid for a uniform $\mathrm{pH}$ of the cheese. The cheeses were vacuum packaged (model X180; Koch Supplies Inc., Kansas City, MO) in $4 \times 6 \mathrm{~cm}, 3$-mL-high barrier nylon-ethyl vinyl alcohol-polyethylene vacuum pouches (Koch Supplies Inc.). The cheeses were then stored at $10^{\circ} \mathrm{C}$ for one week before analysis for TC and SC, total and soluble phosphorus, and total citrate. After analysis, the cheeses were stored at $-27^{\circ} \mathrm{C}$ for later analysis of protein, salt, and moisture.

\section{Compositional Analyses}

All compositional analyses were conducted in duplicate. Milk was analyzed for TS (Marshall, 1992) and TC and SC (Metzger, et al., 2001). Cheeses were analyzed for moisture (Marshall, 1992), protein using the UDY dye-binding method (UDY Corp., Fort Collins, CO) to determine the protein content with a UDY dye-binding colorimeter protein analyzer (UDY Corp.), salt with a Corning salt analyzer (Marshall, 1992), and $\mathrm{pH}$ with a pH meter (Accumet AP61; Fisher Scientific) using an Accumet electrode (serial no. 208804; Fisher Scientific) calibrated with $\mathrm{pH}$ buffer 4 and 7 (Fisher Scientific) before each use.
Table 2. Cheese $\mathrm{pH}$ after pressing, cheese $\mathrm{pH}$ after addition of lactic acid, and approximate volume of lactic acid added to attain the target $\mathrm{pH}$

\begin{tabular}{|c|c|c|c|c|}
\hline Cheese & $\begin{array}{l}\text { Desired } \\
\mathrm{pH}\end{array}$ & $\begin{array}{l}\mathrm{pH} \text { after } \\
\text { pressing }\end{array}$ & $\begin{array}{l}\text { Final } \\
\mathrm{pH}\end{array}$ & $\begin{array}{l}\text { Lactic acid } \\
\text { added, } \mathrm{mL} \\
(85 \%, \mathrm{wt} / \mathrm{vol})\end{array}$ \\
\hline CSM2, & 5.4 & 5.46 & 5.39 & 0.38 \\
\hline \multirow[t]{6}{*}{ Batch 1} & 5.3 & 5.33 & 5.29 & 0.26 \\
\hline & 5.2 & 5.24 & 5.20 & 0.24 \\
\hline & 5.1 & 5.12 & 5.10 & 0.07 \\
\hline & 5.0 & 5.05 & 5.01 & 0.24 \\
\hline & 4.9 & 4.95 & 4.90 & 0.25 \\
\hline & 4.8 & 4.85 & 4.80 & 0.22 \\
\hline CSM2, & 5.4 & 5.42 & 5.40 & 0.10 \\
\hline \multirow{6}{*}{ Batch 2} & 5.3 & 5.35 & 5.30 & 0.32 \\
\hline & 5.2 & 5.23 & 5.19 & 0.24 \\
\hline & 5.1 & 5.16 & 5.11 & 0.19 \\
\hline & 5.0 & 5.05 & 4.99 & 0.36 \\
\hline & 4.9 & 4.94 & 4.91 & 0.15 \\
\hline & 4.8 & 4.86 & 4.79 & 0.30 \\
\hline CSMC2, & 5.4 & 5.46 & 5.38 & 0.48 \\
\hline \multirow{6}{*}{ Batch 1} & 5.3 & 5.32 & 5.31 & 0.05 \\
\hline & 5.2 & 5.25 & 5.18 & 0.15 \\
\hline & 5.1 & 5.13 & 5.10 & 0.21 \\
\hline & 5.0 & 5.06 & 5.10 & 0.30 \\
\hline & 4.9 & 4.95 & 4.90 & 0.40 \\
\hline & 4.8 & 4.87 & 4.81 & 0.22 \\
\hline CSMC2, & 5.4 & 5.46 & 5.39 & 0.46 \\
\hline \multirow[t]{6}{*}{ Batch 2} & 5.3 & 5.35 & 5.30 & 0.24 \\
\hline & 5.2 & 5.26 & 5.21 & 0.11 \\
\hline & 5.1 & 5.13 & 5.11 & 0.14 \\
\hline & 5.0 & 5.04 & 5.00 & 0.24 \\
\hline & 4.9 & 4.90 & 4.90 & 0.00 \\
\hline & 4.8 & 4.84 & 4.78 & 0.22 \\
\hline CSMC3, & 5.4 & 5.43 & 5.41 & 0.12 \\
\hline \multirow[t]{6}{*}{ Batch 1} & 5.3 & 5.34 & 5.28 & 0.31 \\
\hline & 5.2 & 5.25 & 5.20 & 0.18 \\
\hline & 5.1 & 5.15 & 5.09 & 0.29 \\
\hline & 5.0 & 5.03 & 5.01 & 0.16 \\
\hline & 4.9 & 4.93 & 4.91 & 0.12 \\
\hline & 4.8 & 4.81 & 4.81 & 0.00 \\
\hline CSMC3, & 5.4 & 5.44 & 5.40 & 0.24 \\
\hline \multirow[t]{6}{*}{ Batch 2} & 5.3 & 5.33 & 5.31 & 0.10 \\
\hline & 5.2 & 5.21 & 5.21 & 0.00 \\
\hline & 5.1 & 5.11 & 5.11 & 0.00 \\
\hline & 5.0 & 5.04 & 4.99 & 0.39 \\
\hline & 4.9 & 4.93 & 4.89 & 0.24 \\
\hline & 4.8 & 4.86 & 4.80 & 0.34 \\
\hline
\end{tabular}

Calcium Analysis. Total calcium was determined by atomic absorption spectroscopy as adapted from Metzger et al. (2000). Respectively, 0.75 and $1.5 \mathrm{~g}$ of milk and cheese were used. Milk and cheese were mixed with 29.25 and $45 \mathrm{~g}$ of $12 \%$ (wt/vol) TCA (J.T.Baker), respectively, and homogenized for $60 \mathrm{~s}$ (UltraTurrax TP-18/10S1; IKA Works, Inc., Wilmington, NC). After 10 min rest, homogenates were filtered using Whatman \#4 filter paper (Whatman International Ltd., Maidstone, UK). Water-soluble calcium in milk and cheese were assayed using the same technique of Metzger et al. (2001), with slight modifications in determination of SC in cheese. To extract SC, $5 \mathrm{~g}$ of milk was mixed with $50 \mathrm{~g}$ of water $\left(60^{\circ} \mathrm{C}\right)$ for $60 \mathrm{~s}$ with a homogenizer 
(UltraTurrax TP-18/10S1; IKA Works, Inc.). To extract $\mathrm{SC}, 5 \mathrm{~g}$ of cheese was blended with $50 \mathrm{~g}$ of phosphate buffer $\left(60^{\circ} \mathrm{C}\right)$ for $60 \mathrm{~s}$. The phosphate buffer and cheese had equivalent $\mathrm{pH}$ to prevent any changes in $\mathrm{pH}$ that might influence modification of the calcium equilibrium between the insoluble and soluble phases (Hassan et al., 2004). Cheeses were not analyzed using the cheese juice method (Lucey and Fox, 1993) because of the large sample size required (approximately $800 \mathrm{~g}$ for one analysis; Hassan, et al., 2004). The milk and cheese slurry were then filtered using Whatman \#4 filter paper (Whatman International Ltd.). For milk, $1 \mathrm{~g}$ of filtrate was mixed with $9.6 \mathrm{~g}$ of a $3 \%$ (wt/vol) nitric acid solution (J.T.Baker) and $0.4 \mathrm{~g}$ of a $5 \%$ (wt/vol) lanthanum oxide solution (Sigma-Aldrich, St. Louis, MO). For cheese, 1 $\mathrm{g}$ of filtrate was mixed with $9.6 \mathrm{~g}$ of a $3 \%(\mathrm{wt} / \mathrm{vol})$ nitric acid solution (J.T.Baker) and $0.4 \mathrm{~g}$ of a $5 \%$ (wt/vol) lanthanum oxide solution (Sigma-Aldrich), and the milk and cheese filtrates were further diluted 10 and 20 times, respectively, with 3\% nitric acid (J.T.Baker). Diluted milk and cheese filtrates were aspirated into the atomic absorption spectrophotometer (model SpectrAA 220; Varian Inc.) fitted with a Varian Ca/Mg lamp (serial no. 5610107100; Varian Inc.) for calcium determination at a wavelength of $422.7 \mathrm{~nm}$, in accordance with the manufacturer's instructions. The atomic absorption spectrophotometer was calibrated with reference standards $0,1,2,4$, and $5 \mathrm{ppm}$, prepared from a $1,000 \pm 1 \%$ calcium reference solution (SC191-100; Fisher Scientific). Reference standards contained 3\% nitric acid and $0.02 \%$ (wt/vol) lanthanum oxide (Sigma-Aldrich).

Phosphorus. Total and soluble phosphorus were determined using colorimetry (Pollman, 1991) following modifications in the determination of total and soluble phosphorus in cheese. To determine total phosphorus, $1.5 \mathrm{~g}$ of cheese was mixed with $45 \mathrm{~g}$ of TCA (J.T.Baker) and blended for $60 \mathrm{~s}$ with a homogenizer (UltraTurrax TP-18/10S1; IKA Works, Inc.). To extract soluble phosphate, $5 \mathrm{~g}$ of cheese was blended with $50 \mathrm{~g}$ of water for $60 \mathrm{~s}$ with a homogenizer (UltraTurrax TP-18/10S1; IKA Works, Inc.). The cheese slurry was filtered using Whatman \#4 filter paper (Whatman International Ltd.), and $1 \mathrm{~g}$ of filtrate was mixed with $3 \mathrm{~g}$ of concentrated nitric acid (J.T.Baker) to convert any organic phosphate into inorganic phosphate. Preparation of the standard curve and determination of phosphorus in the sample were adapted from Pollman (1991). Total and soluble phosphorus samples were analyzed using an Ultrospec 4000 UV-visible spectrophotometer (Pharmacia Biotech Co., Cambridge, UK).

Citrate, Lactate, and Lactose. Citrate, lactate, and lactose were measured using R-Biopharm Enzymatic Bioanalysis test kits (Boehringer Mannheim En- zymatic Bioanalysis/Food Analysis Test Kits; Boehringer Mannheim, Darmstadt, Germany) following the instructions provided by the manufacturer. Intensity of the CLC was measured using the scale of Agarwal et al. (2005). White crystals on the surface of cheeses were analyzed for lactic acid using R-Biopharm Enzymatic Bioanalysis test kits (Boehringer Mannheim Enzymatic Bioanalysis/Food Analysis Test Kits; Boehringer Mannheim).

\section{Statistical Analysis}

The statistical design (ANOVA) was based on a splitplot experimental design (Kuehl, 2000). A $3 \times 7$ factorial design with 2 replications was used for statistical analysis. The same batch of pasteurized skim milk was used for making all cheeses. Data were analyzed with least significant differences using the SAS procedure PROC GLM (SAS Institute, 2005) and involved TC, SC, total phosphorus, soluble phosphorus, lactic acid, and salt as class variables. To determine correlations among different class variables (TC, SC, total phosphorus, soluble phosphorus, lactic acid, salt, and CLC), the SAS procedure PROC CORR was used (SAS Institute, 2005). To determine correlations between $\mathrm{pH}$ and the occurrence of CLC in cheese, the presence of crystals on cheese surfaces was recorded as 1 and the absence of crystals on cheese surfaces was taken as 0 , and the SAS procedure PROC CORR Kendall Tau-b was used (SAS Institute, 2005).

\section{RESULTS}

\section{Milk}

In trial 1 , the initial $\mathrm{pH}$ of CSM1 $(\mathrm{pH}=6.52)$ was lower than the $\mathrm{pH}$ of SM1 $(\mathrm{pH}=6.74)$ because of the increased TS (Table 1). An increase in TS generally decreases the $\mathrm{pH}$ of milk because of the increased concentration of $\mathrm{CN}$ micelles that are negatively charged, which leads to decreases in the $\mathrm{pH}$ and increases in the buffering capacity of milk (Fox, 2003). The $\mathrm{pH}$ of the SM1 and CSM1 were not buffered to an equivalent initial $\mathrm{pH}$ to ensure a process similar to that used by a cheese maker when concentrating cheese milk with milk solids. A significantly larger concentration of calcium $(P<0.05)$ was observed in CSM1 compared with SM1 (Figure 1), similar to results recorded by Lee et al. (2005). As the $\mathrm{pH}$ of SM1 was lowered from an initial $\mathrm{pH}$ of 6.74 to a $\mathrm{pH}$ of 5.00 , the amount of SC increased from 51.5 to $116.5 \mathrm{mg} / 100 \mathrm{~g}$ of milk, an increase of $126 \%$. Similarly, as the $\mathrm{pH}$ of CSM1 was lowered from a pH of 6.52 to a pH of 5.00, the amount of SC increased from 65.5 to $157.4 \mathrm{mg} / 100 \mathrm{~g}$ of milk, an increase of $140 \%$. Larger concentrations of TC in CSM1 (average 


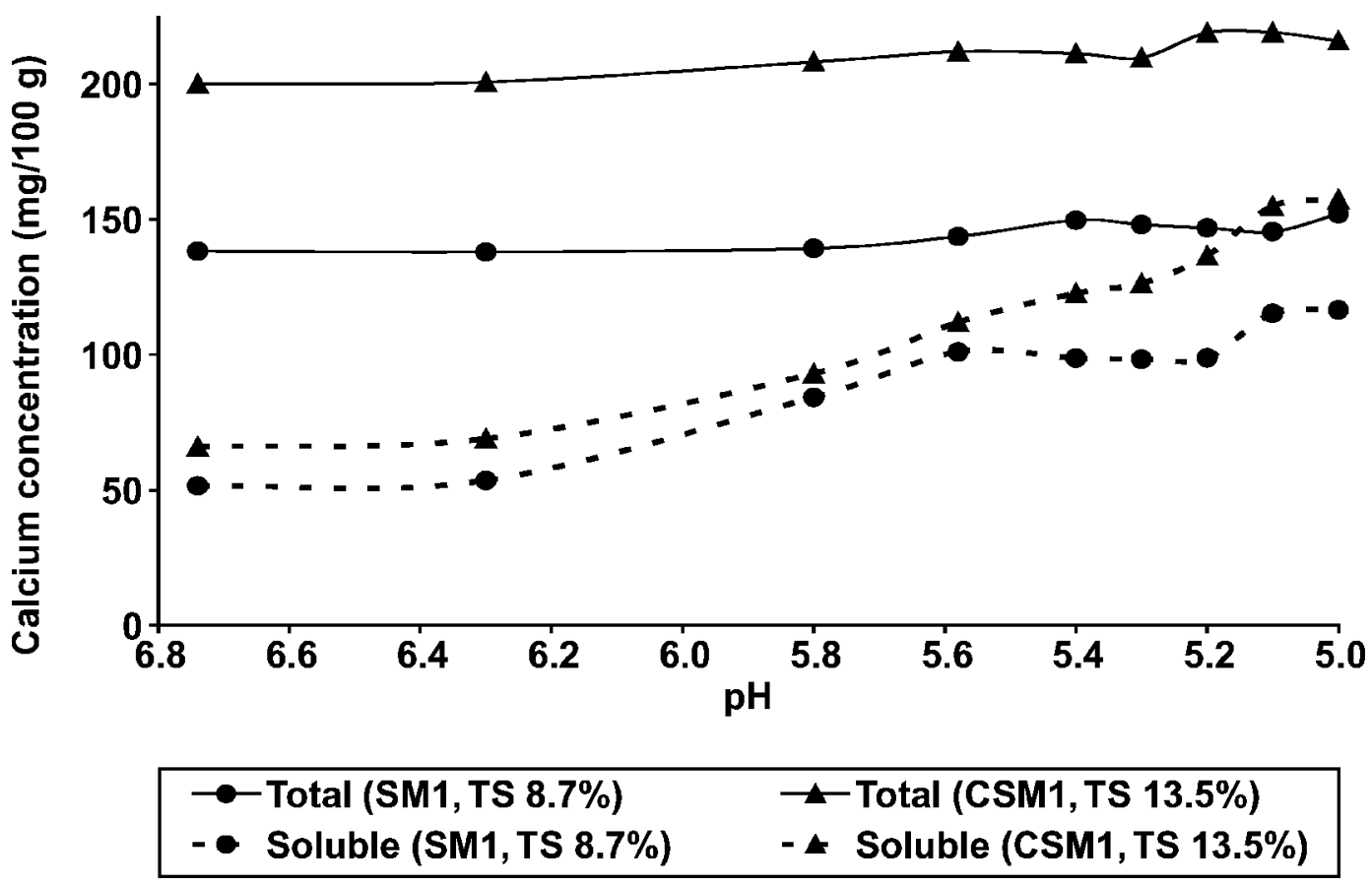

Figure 1. Total and soluble calcium in skim milk (SM1) and concentrated skim milk (CSM1) at pH 6.8 to 5.0.

$210 \mathrm{mg} / 100 \mathrm{~g}$ ) compared with SM1 (average $145 \mathrm{mg} /$ $100 \mathrm{~g}$ ) showed that increasing the TS in milk increased the TC concentration. Increased cheese TC leads to increased SC in the final cheese unless some of the SC is removed during cheese making by including steps such as washing of the curd. During the manufacture of Cheddar cheeses, cheese curds are milled and salted between $\mathrm{pH} 5.5$ and 5.4, and the final $\mathrm{pH}$ of the cheese after manufacture can range from 5.3 to 4.9 (Fox, 1993). Increasing the TS of SM1 from 8.7 to $13.5 \%$ by addition of NDM increased the amount of SC in SM1 at pH 5.2 from 98.8 to $136.5 \mathrm{mg} / 100 \mathrm{~g}$ of milk, an increase of $38 \%$ (Figure 1). Increased SC in the serum phase of cheese can easily combine with lactate to form CLC if the concentration of the SC and lactate increases above saturation (Dybing, et al., 1988). This also explains why cheeses with CLC have low $\mathrm{pH}$ compared with cheeses with no CLC, as lower $\mathrm{pH}$ in cheeses can lead to an increased concentration of SC and lactate (Rajbhandari and Kindstedt, 2005).

\section{Cheese}

Significantly $(P<0.05)$ higher protein concentrations were observed in CSMC2 (48.43\%) and CSMC3 (48.02\%) cheeses compared with SMC2 (46.28\%; Table $3)$. A significantly higher $(P<0.05)$ lactose concentration was observed in CSMC3 compared with SMC2 and
CSMC2 cheeses (Table 3). The moisture concentration in cheeses ranged from 42 to $45 \%$, which was rather high compared with commercial full-fat cheese, but well below the legal limit of not more than $50 \%$ for skim milk cheese (FDA, 2005). Mean salt-to-moisture ratios in SMC2, CSMC2, and CSMC3 cheeses ranged from 3.5 to $4.6 \%$ (Table 3 ); close to the $4.0 \%$ range is the aim of most cheese manufacturers. The total percentage of lactic acid [sum of $\mathrm{L}(+)$ - and $\mathrm{D}(-)$-lactic acids] in cheeses increased as the $\mathrm{pH}$ of the cheeses decreased from 5.4 to 4.8 , as expected. More than $90 \%$ of the lactic acid present in cheeses was in the $\mathrm{L}(+)$ form. In SMC2, total lactic acid increased from $1.25 \mathrm{~g} / 100 \mathrm{~g}$ at $\mathrm{pH} 5.4$ to 2.87 $\mathrm{g} / 100 \mathrm{~g}$ at $\mathrm{pH} 4.8$, an increase of $130 \%$. Similarly, in CSMC2 and CSMC3 the total lactic acid increased from 1.44 and $1.47 \mathrm{~g} / 100 \mathrm{~g}$ to 3.06 and $3.15 \mathrm{~g} / 100 \mathrm{~g}$ of lactic acid, increases of 112 and $114 \%$, respectively, as the $\mathrm{pH}$ of the cheese decreased from 5.4 to 4.8. An increased concentration of lactic acid $(>1.4 \%)$ in Cheddar cheese has been implicated in the occurrence of CLC (Johnson, 2004). In the current study, increased lactic acid concentrations $(>1.4 \%)$ were related to CLC in cheeses made only from concentrated cheese milk with increased protein concentration. Calcium lactate crystals were observed in CSMC2 and CSMC3 at $\mathrm{pH}$ 5.3, with lactic acid concentrations of 1.68 and $1.78 \%$, whereas no CLC were observed in SMC2 at pH 5.2 even though the lactic acid concentration was $1.89 \%$ (Table 3 ). 
Table 3. Composition of cheeses made from skim milk (SMC2), skim milk supplemented with UF milk (CSMC2), and skim milk supplemented with NDM (CSMC3) ${ }^{1}$

\begin{tabular}{|c|c|c|c|c|c|c|c|}
\hline \multirow[b]{2}{*}{ Composition } & \multicolumn{7}{|c|}{ SMC2 } \\
\hline & pH 5.4 & pH 5.3 & $\mathrm{pH} 5.2$ & $\mathrm{pH} 5.1$ & $\mathrm{pH} 5.0$ & $\mathrm{pH} 4.9$ & $\mathrm{pH} 4.8$ \\
\hline Salt, $\%$ & $1.83 \pm 0.00^{\mathrm{a}}$ & $1.88 \pm 0.01^{\mathrm{a}}$ & $1.65 \pm 0.05^{\mathrm{a}}$ & $1.75 \pm 0.08^{\mathrm{a}}$ & $2.00 \pm 0.12^{\mathrm{a}}$ & $1.70 \pm 0.06^{\mathrm{a}}$ & $1.80 \pm 0.15^{\mathrm{a}}$ \\
\hline Moisture, \% & $42.03 \pm 0.75^{\mathrm{a}}$ & $41.68 \pm 0.84^{\mathrm{a}}$ & $42.26 \pm 1.18^{\mathrm{a}}$ & $41.58 \pm 1.27^{\mathrm{a}}$ & $41.78 \pm 1.36^{\mathrm{a}}$ & $42.14 \pm 1.58^{\mathrm{a}}$ & $42.22 \pm 1.54^{\mathrm{a}}$ \\
\hline Salt-in-moisture, $\%$ & $4.36 \pm 0.55^{\mathrm{a}}$ & $4.48 \pm 0.64^{\mathrm{a}}$ & $3.92 \pm 0.22^{\mathrm{a}}$ & $4.17 \pm 0.15^{\mathrm{a}}$ & $4.77 \pm 0.24^{\mathrm{a}}$ & $4.06 \pm 0.07^{\mathrm{a}}$ & $4.28 \pm 0.26^{\mathrm{a}}$ \\
\hline Lactose, $\%$ & $0.65 \pm 0.23^{\mathrm{a}}$ & $0.56 \pm 0.19^{\mathrm{ab}}$ & $0.47 \pm 0.17^{\mathrm{b}}$ & $0.42 \pm 0.08^{b}$ & $0.34 \pm 0.13^{\mathrm{bc}}$ & $0.27 \pm 0.03^{\mathrm{c}}$ & $0.20 \pm 0.11^{\mathrm{c}}$ \\
\hline Lactic acid, \% & $1.25 \pm 0.06^{\mathrm{a}}$ & $1.58 \pm 0.02^{\mathrm{b}}$ & $1.89 \pm 0.16^{\mathrm{c}}$ & $2.08 \pm 0.23^{\mathrm{d}}$ & $2.39 \pm 0.03^{\mathrm{e}}$ & $2.65 \pm 0.43^{\mathrm{e}}$ & $2.87 \pm 0.39^{f}$ \\
\hline Total calcium, mg/100 g & $1,064.5 \pm 31.5^{\mathrm{a}}$ & $1,072.3 \pm 84.7^{\mathrm{a}}$ & $1,081.6 \pm 27.4^{\mathrm{a}}$ & $1,059.8 \pm 94.9^{\mathrm{a}}$ & $1,042.6 \pm 66.4^{\mathrm{a}}$ & $1,071.5 \pm 64.2^{\mathrm{a}}$ & $1,071.1 \pm 86.5^{\mathrm{a}}$ \\
\hline Soluble calcium, mg/100 g & $297.2 \pm 12.2^{\mathrm{a}}$ & $405.0 \pm 29.3^{\mathrm{b}}$ & $441.7 \pm 18.5^{\mathrm{c}}$ & $480.2 \pm 36.0^{\mathrm{d}}$ & $497.9 \pm 36.4^{\mathrm{e}}$ & $508.5 \pm 24.7^{\mathrm{f}}$ & $565.6 \pm 28.2^{\mathrm{g}}$ \\
\hline Total phosphorus, mg/100 g & $141.3 \pm 1.1^{\mathrm{a}}$ & $134.6 \pm 2.2^{\mathrm{a}}$ & $135.1 \pm 9.0^{\mathrm{a}}$ & $135.2 \pm 3.9^{\mathrm{a}}$ & $132.8 \pm 9.8^{\mathrm{a}}$ & $129.8 \pm 11.1^{\mathrm{a}}$ & $129.0 \pm 6.3^{\mathrm{a}}$ \\
\hline \multirow[t]{3}{*}{ Soluble phosphorus, mg/100 g } & $55.0 \pm 0.4^{\mathrm{a}}$ & $57.8 \pm 0.3^{\mathrm{b}}$ & $61.9 \pm 1.3^{\mathrm{c}}$ & $65.2 \pm 2.5^{\mathrm{d}}$ & $66.1 \pm 4.8^{\mathrm{e}}$ & $68.7 \pm 6.6^{\mathrm{e}}$ & $66.6 \pm 4.8^{\mathrm{e}}$ \\
\hline & \multicolumn{7}{|c|}{ CSMC2 } \\
\hline & pH 5.4 & $\mathrm{pH} 5.3$ & pH 5.2 & $\mathrm{pH} 5.1$ & $\mathrm{pH} 5.0$ & $\mathrm{pH} 4.9$ & $\mathrm{pH} 4.8$ \\
\hline Salt, $\%$ & $1.67 \pm 0.03^{\mathrm{a}}$ & $1.54 \pm 0.01^{\mathrm{a}}$ & $1.75 \pm 0.08^{\mathrm{a}}$ & $1.76 \pm 0.02^{\mathrm{a}}$ & $1.72 \pm 0.04^{\mathrm{a}}$ & $1.82 \pm 0.11^{\mathrm{a}}$ & $1.62 \pm 0.04^{\mathrm{a}}$ \\
\hline Moisture, \% & $44.53 \pm 1.38$ & $43.11 \pm 1.52$ & $43.41 \pm 1.65$ & $45.00 \pm 1.45$ & $42.77 \pm 1.27$ & $43.96 \pm 1.73$ & $43.73 \pm 1.86$ \\
\hline Salt-in-moisture, \% & $3.74 \pm 0.40^{\mathrm{a}}$ & $3.58 \pm 0.02^{\mathrm{a}}$ & $4.03 \pm 0.08^{\mathrm{a}}$ & $3.91 \pm 0.04^{\mathrm{a}}$ & $4.02 \pm 0.07^{\mathrm{a}}$ & $4.14 \pm 0.43^{\mathrm{a}}$ & $3.70 \pm 0.09^{\mathrm{a}}$ \\
\hline Lactose, \% & $0.78 \pm 0.10^{\mathrm{a}}$ & $0.70 \pm 0.04^{\mathrm{a}}$ & $0.67 \pm 0.16^{\mathrm{ab}}$ & $0.55 \pm 0.06^{\mathrm{b}}$ & $0.45 \pm 0.11^{\mathrm{bc}}$ & $0.32 \pm 0.08^{\mathrm{c}}$ & $0.25 \pm 0.09^{\mathrm{c}}$ \\
\hline Lactic acid, \% & $1.44 \pm 0.21^{\mathrm{a}}$ & $1.68 \pm 0.04^{\mathrm{b}}$ & $1.79 \pm 0.09^{\mathrm{c}}$ & $2.15 \pm 0.07^{\mathrm{d}}$ & $2.46 \pm 0.01^{\mathrm{e}}$ & $2.87 \pm 0.01^{\mathrm{f}}$ & $3.06 \pm 0.07^{\mathrm{g}}$ \\
\hline Total calcium, mg/100 g & $1,351.8 \pm 29.3^{\mathrm{a}}$ & $1,375.7 \pm 42.4^{\mathrm{a}}$ & $1,376.1 \pm 26.6^{\mathrm{a}}$ & $1,367.3 \pm 28.2^{\mathrm{a}}$ & $1,370.3 \pm 66.3^{\mathrm{a}}$ & $1,356.7 \pm 22.8^{\mathrm{a}}$ & $1,371.3 \pm 52.8^{\mathrm{a}}$ \\
\hline Soluble calcium, mg/100 g & $432.5 \pm 12.2^{\mathrm{a}}$ & $499.0 \pm 5.8^{\mathrm{b}}$ & $550.9 \pm 18.2^{\mathrm{c}}$ & $610.7 \pm 6.3^{\mathrm{d}}$ & $647.7 \pm 22.2^{\mathrm{e}}$ & $705.4 \pm 38.3^{\mathrm{f}}$ & $728.9 \pm 11.2^{\mathrm{g}}$ \\
\hline Total phosphorus, mg/100 g & $245.2 \pm 9.4^{\mathrm{a}}$ & $240.4 \pm 14.3^{\mathrm{a}}$ & $251.2 \pm 16.0^{\mathrm{a}}$ & $243.4 \pm 10.6^{\mathrm{a}}$ & $251.0 \pm 9.8^{\mathrm{a}}$ & $247.6 \pm 12.4^{\mathrm{a}}$ & $250.5 \pm 11.6^{\mathrm{a}}$ \\
\hline \multirow[t]{3}{*}{ Soluble phosphorus, mg/100 g } & $92.5 \pm 2.0^{\mathrm{a}}$ & $92.0 \pm 3.3^{\mathrm{a}}$ & $98.1 \pm 1.7^{\mathrm{b}}$ & $102.3 \pm 1.8^{\mathrm{c}}$ & $109.2 \pm 6.2^{\mathrm{d}}$ & $110.0 \pm 2.9^{\mathrm{d}}$ & $107.2 \pm 3.4^{\mathrm{d}}$ \\
\hline & \multicolumn{7}{|c|}{ CSMC3 } \\
\hline & $\mathrm{pH} 5.4$ & pH 5.3 & pH 5.2 & $\mathrm{pH} 5.1$ & pH 5.0 & $\mathrm{pH} 4.9$ & $\mathrm{pH} 4.8$ \\
\hline Salt $\%$ & $1.84 \pm 0.01^{\mathrm{a}}$ & $1.93 \pm 0.06^{\mathrm{a}}$ & $2.01 \pm 0.11^{\mathrm{a}}$ & $1.85 \pm 0.05^{\mathrm{a}}$ & $1.95 \pm 0.10^{\mathrm{a}}$ & $1.67 \pm 0.04^{\mathrm{a}}$ & $1.93 \pm 0.09^{\mathrm{a}}$ \\
\hline Moisture, \% & $44.79 \pm 1.03^{\mathrm{a}}$ & $45.99 \pm 1.26^{\mathrm{a}}$ & $43.81 \pm 1.81^{\mathrm{a}}$ & $43.67 \pm 1.65^{\mathrm{a}}$ & $43.35 \pm 1.94^{\mathrm{a}}$ & $43.59 \pm 1.79^{\mathrm{a}}$ & $42.47 \pm 0.98^{\mathrm{a}}$ \\
\hline Salt-in-moisture, \% & $4.11 \pm 0.52^{\mathrm{a}}$ & $4.19 \pm 0.58^{\mathrm{a}}$ & $4.58 \pm 0.35^{\mathrm{a}}$ & $4.24 \pm 0.67^{\mathrm{a}}$ & $4.49 \pm 0.62^{\mathrm{a}}$ & $3.84 \pm 0.57^{\mathrm{a}}$ & $4.54 \pm 0.32^{\mathrm{a}}$ \\
\hline Lactose, $\%$ & $1.68 \pm 0.26^{\mathrm{a}}$ & $1.59 \pm 0.11^{\mathrm{a}}$ & $1.53 \pm 0.17^{\mathrm{ab}}$ & $1.45 \pm 0.05^{\mathrm{b}}$ & $1.31 \pm 0.07^{\mathrm{c}}$ & $1.21 \pm 0.13^{\mathrm{c}}$ & $1.11 \pm 0.06^{\mathrm{c}}$ \\
\hline Lactic acid, \% & $1.47 \pm 0.23^{\mathrm{a}}$ & $1.73 \pm 0.08^{\mathrm{b}}$ & $1.91 \pm 0.25^{\mathrm{c}}$ & $2.16 \pm 0.38^{\mathrm{d}}$ & $2.56 \pm 0.22^{\mathrm{e}}$ & $2.86 \pm 0.52^{\mathrm{e}}$ & $3.15 \pm 0.25^{\mathrm{f}}$ \\
\hline Total calcium, mg/100 g & $1,352.9 \pm 15.3^{\mathrm{a}}$ & $1,374.2 \pm 63.6^{\mathrm{a}}$ & $1,402.8 \pm 53.5^{\mathrm{a}}$ & $1,391.0 \pm 65.6^{\mathrm{a}}$ & $1,377.5 \pm 78.3^{\mathrm{a}}$ & $1,373.8 \pm 103.3^{\mathrm{a}}$ & $1,359.4 \pm 82.4^{\mathrm{a}}$ \\
\hline Soluble calcium, mg/100 g & $420.6 \pm 21.9^{\mathrm{a}}$ & $491.5 \pm 30.7^{\mathrm{b}}$ & $558.5 \pm 38.9^{\mathrm{c}}$ & $610.9 \pm 35.7^{\mathrm{d}}$ & $629.7 \pm 15.2^{\mathrm{e}}$ & $677.0 \pm 14.0^{\mathrm{f}}$ & $728.5 \pm 35.6^{\mathrm{g}}$ \\
\hline Total phosphorus, mg/100 g & $241.7 \pm 10.6^{\mathrm{a}}$ & $239.7 \pm 11.6^{\mathrm{a}}$ & $239.8 \pm 11.1^{\mathrm{a}}$ & $246.3 \pm 5.6^{\mathrm{a}}$ & $250.4 \pm 13.3^{\mathrm{a}}$ & $231.0 \pm 7.7^{\mathrm{a}}$ & $238.4 \pm 15.7^{\mathrm{a}}$ \\
\hline Soluble phosphorus, mg/100 g & $91.2 \pm 1.5^{\mathrm{a}}$ & $93.1 \pm 1.4^{\mathrm{b}}$ & $94.0 \pm 4.0^{\mathrm{b}}$ & $104.8 \pm 4.5^{\mathrm{c}}$ & $108.1 \pm 4.8^{\mathrm{d}}$ & $111.0 \pm 3.7^{\mathrm{e}}$ & $111.6 \pm 3.0^{\mathrm{e}}$ \\
\hline
\end{tabular}

${ }^{\mathrm{a}-\mathrm{g}}$ Means within the same category (salt, salt-in-moisture, lactic acid, total calcium, soluble calcium, total phosphorus, and soluble phosphorus) sharing common superscripts are similar $(P>0.05)$.

${ }^{1}$ Means of replicates \pm SD. Protein contents (\%) of cheeses were as follows: SMC2, 46.28 \pm 0.75 ; CSMC2, 48.43 \pm 0.44 ; CSMC3, 48.02 \pm 0.20 . 


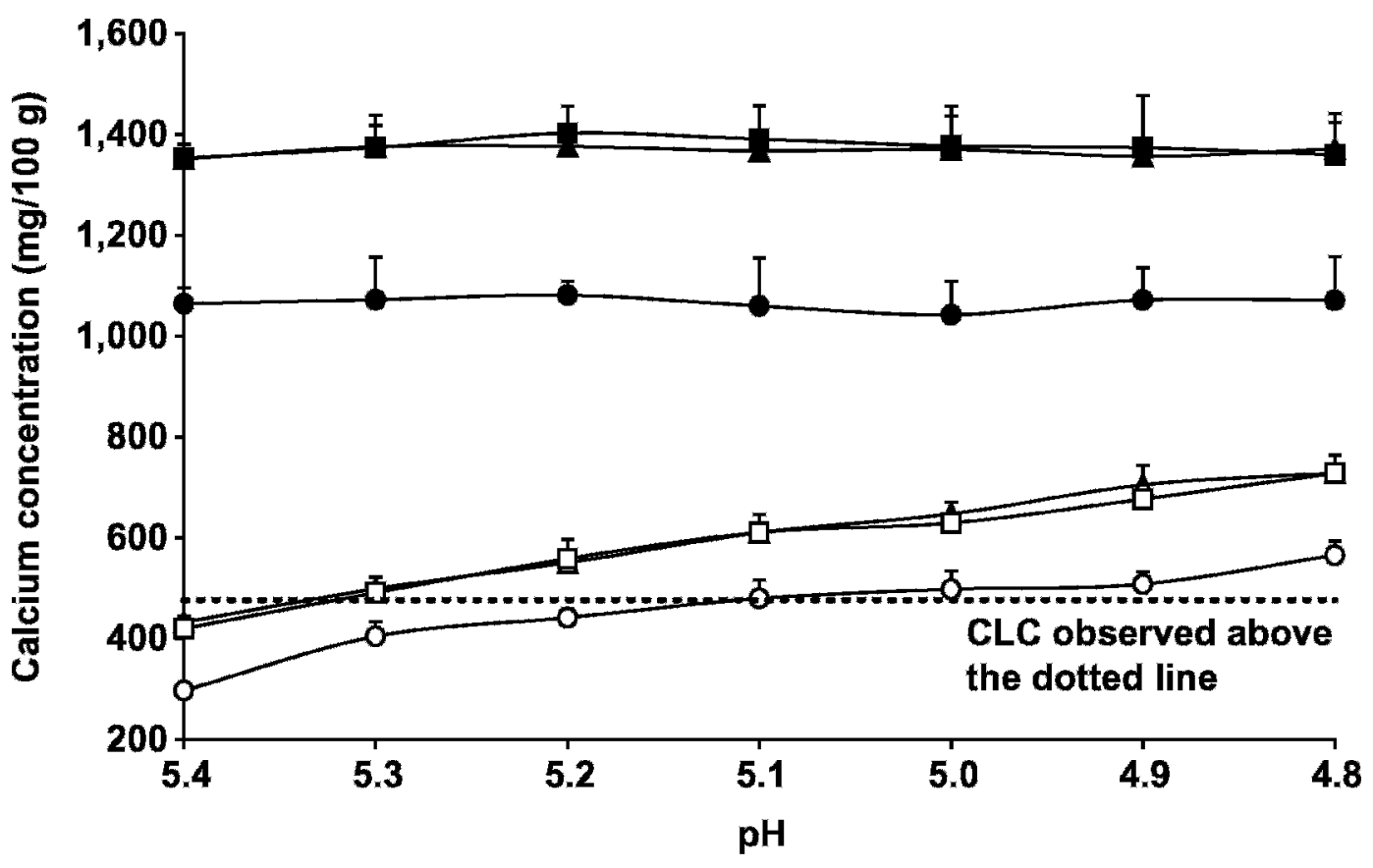

\begin{tabular}{|c|c|}
\hline 2 (Total) & - CSMC2 (Total) \\
\hline
\end{tabular}

Figure 2. Total and soluble calcium in cheeses made from skim milk (SMC2), skim milk supplemented with UF milk (CSMC2), and skim milk supplemented with NDM (CSMC3) at pH 5.4 to 4.8. CLC = calcium lactate crystals.

\section{TC and SC}

No significant differences were observed between mean TC in CSMC2 $(1,367 \mathrm{mg} / 100 \mathrm{~g})$ and CSMC3 $(1,375 \mathrm{mg} / 100 \mathrm{~g})$ cheeses, but both were significantly $(P<0.05)$ larger than SMC2 $(1,066 \mathrm{mg} / 100 \mathrm{~g}$; Figure 2). Larger TC concentrations in CSMC2 and CSMC3 compared with SMC2 confirmed that calcium is associated with proteins in cheese milk, because the protein concentrations of CSMC2 and CSMC3 were equivalent, $6.80 \%$ (Table 3). Lee et al. (2005) also showed that cheeses made from reverse osmosis-treated milk contained increased protein and calcium compared with cheeses made from regular milk. The TC values in SCM2, CSMC2, and CSMC3 were all larger than those observed by other researchers in whole milk cheeses (680 to $833 \mathrm{mg} / 100$ g; Hassan et al., 2004; Swearingen et al., 2004). The difference can be explained by the presence of 28 to $35 \%$ fat in whole milk cheese (Fox, 1993), which reduces the TC observed in whole milk cheese by equal percentages compared with skim milk cheeses. A significant $(P<0.05)$ negative correlation $(-0.60)$ was observed between TC and salt in all the cheeses, demonstrating that as the concentration of salt increased, TC decreased. An increased salt concentra- tion tends to expel more moisture from cheese, leading to a decreased concentration of TC and other minerals in the cheese.

The SC levels in skim milk cheeses were similar to the SC values observed by Swearingen et al. (2004; approximately $450 \mathrm{mg} / 100 \mathrm{~g}$ ). No significant differences were observed in the amounts of SC present in CSMC2 and CSMC3 cheeses throughout the $\mathrm{pH}$ range of 5.4 to 4.8 (Figure 2). Significantly $(P<0.05)$ higher SC was observed throughout the $\mathrm{pH}$ range of 5.4 to 4.8 in CSMC2 and CSMC3 cheeses when compared with SMC2 cheese (Figure 2). A significant increase in SC was observed as the $\mathrm{pH}$ of the cheeses decreased by 0.1 unit throughout the $\mathrm{pH}$ range of 5.4 to 4.8. An increase in $\mathrm{SC}$ with a decrease in the $\mathrm{pH}$ of cheese is relevant because the $\mathrm{pH}$ of finished Cheddar cheese typically ranges from 5.2 to 5.0 (Swearingen, et al., 2004). In $\mathrm{SMC2}$, as the $\mathrm{pH}$ of the cheese decreased from 5.4 to 4.8 , the amount of SC increased significantly $(P<0.05)$. As the $\mathrm{pH}$ of the cheese declined from 5.4 to 5.1 , the amount of SC increased by $61.6 \%$ in SMC2, $41.4 \%$ in CSMC2, and $45.5 \%$ in CSMC3. As the $\mathrm{pH}$ of the experimental cheeses declined from 5.4 to 5.1 or lower, the amount of SC increased (Figure 2) along with increases in concentrations of lactic acid (Table 3). 


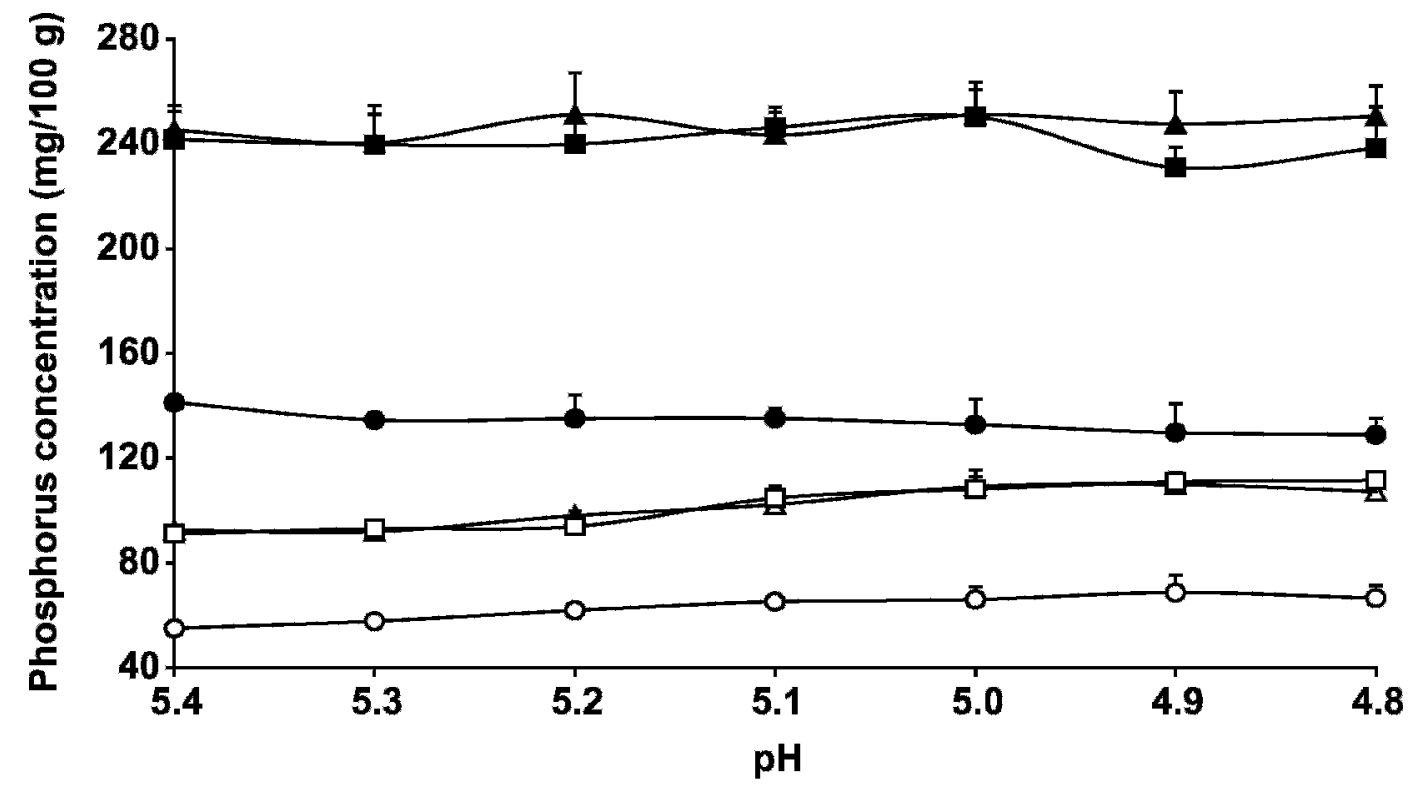

\begin{tabular}{|c|c|c|}
\hline$\rightarrow-$ SMC2 (Total) & \pm -CSMC2 (Total) & $-\operatorname{CSMC} 3$ (Total) \\
\hline - - SMC2 (Soluble) & $\triangle \operatorname{CSMC2}$ (Soluble) & - - $\operatorname{csMC3}$ (Soluble) \\
\hline
\end{tabular}

Figure 3. Total and soluble phosphorus in cheeses made from skim milk (SMC2), skim milk supplemented with UF milk (CSMC2), and skim milk supplemented with NDM (CSMC3) at $\mathrm{pH} 5.4$ to 4.8 .

\section{Total and Soluble Phosphorus}

Concentrations of total phosphorus in SMC2, CSMC2, and CSMC3 were lower than those reported by Lucey and Fox (1993) and Upreti and Metzger (2006). One possible reason for the low values of total phosphorus can be the form in which phosphorus exists. Bound phosphorus can exist in 2 forms: organic phosphate (covalently linked to phosphoserine residues of milk protein) and bound (associated with milk protein as calcium phosphate; Upreti and Metzger, 2006). Use of TCA extracted only the bound calcium and not the organic phosphate, because it is difficult to solubilize organic phosphate, which is covalently linked to phosphoserine at low $\mathrm{pH}$. No significant differences were observed in mean total phosphorus in the CSMC2 (241 $\mathrm{mg} / 100 \mathrm{~g}$ ) and CSMC3 (247 mg/100 g) cheeses (Figure 3 ), confirming that phosphorus is associated with proteins in cheese milk, because the protein concentrations of CSMC2 and CSMC3 were equal, 6.80\% (Table 1). Significantly $(P<0.05)$ higher mean total phosphorus was observed throughout the $\mathrm{pH}$ range from 5.4 to 4.8 in the CSMC2 $(241 \mathrm{mg} / 100 \mathrm{~g})$ and CSMC3 $(247 \mathrm{mg} / 100$ g) cheeses compared with the SMC2 $(134 \mathrm{mg} / 100 \mathrm{~g})$ cheese (Figure 3$)$. Significant $(P<0.05)$ negative correlations $(-0.63)$ were observed between total phosphorus and salt in the cheeses, showing that as the concentrations of salt increased, the concentrations of total phosphorus decreased. An increased salt concentration tends to expel more moisture from cheese, leading to a decreased concentration of total phosphorus in the cheese.

No significant differences were observed in concentrations of soluble phosphorus present in the CSMC2 and CSMC3 cheeses throughout pH 5.4 to 4.8 (Figure $3)$. However, significantly $(P<0.05)$ greater soluble phosphorus concentrations were observed throughout $\mathrm{pH}$ ranging from 5.4 to 4.8 in the CSMC2 and CSMC3 cheeses when compared with the SMC2 cheese (Figure 3).

In SMC2, as the $\mathrm{pH}$ of the cheese decreased from $\mathrm{pH} 5.4$ to 4.8 , the concentration of soluble phosphorus increased significantly $(P<0.05)$. As the $\mathrm{pH}$ of the cheese was reduced from $\mathrm{pH} 5.4$ to 5.1 , the concentration of soluble phosphorus increased by $18.2 \%$ in SMC2, by $10.8 \%$ in CSMC2, and by $15.4 \%$ in CSMC3. Between $\mathrm{pH} 5.0$ and 4.8, no significant changes in concentrations of soluble phosphorus were observed (Figure 3). Lucey and Fox (1993) reported that virtually all the bound phosphate in milk was soluble at $\mathrm{pH}$ 5.0, supporting these results. 


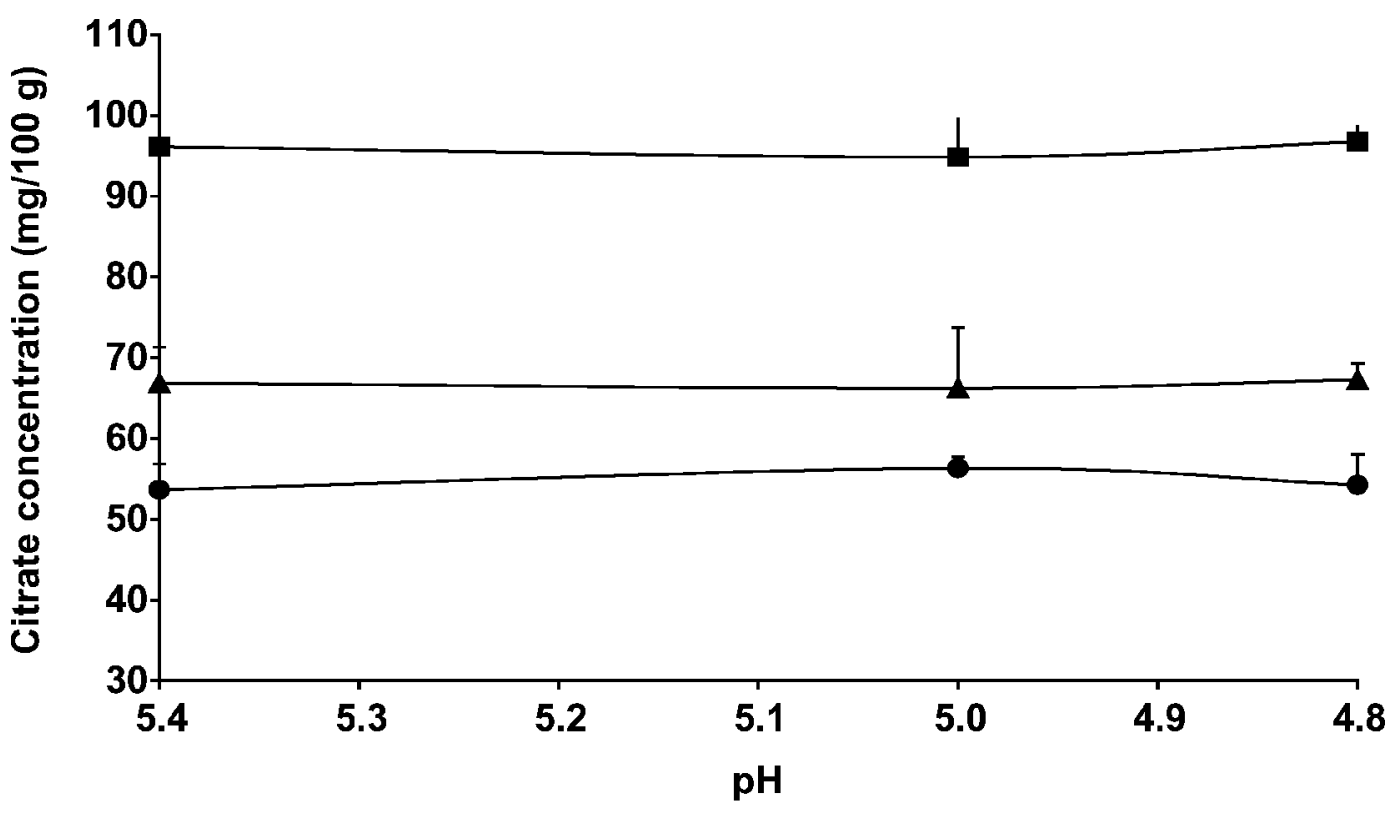

$\bullet-\operatorname{SMC2}($ Total) $\rightarrow$ CSMC2 (Total) $\rightarrow$-CSMC3 (Total)

Figure 4. Citrate concentration in cheeses made from skim milk (SMC2), skim milk supplemented with UF milk (CSMC2), and skim milk supplemented with NDM (CSMC3) at pH 5.4 to 4.8.

\section{Citrate}

Significantly $(P<0.05)$ greater total citrate concentrations were observed throughout $\mathrm{pH}$ ranging from 5.4 to 4.8 in the CSMC3 cheese compared with those in the CSMC2 and SMC2 cheeses (Figure 4). A probable reason for the smaller total citrate concentrations in CSMC2 compared with CSMC3 is the loss of citrate in the permeate during UF, whereas no loss of citrate took place while manufacturing NDM. Significant $(P<0.05)$ differences were observed in total citrate between the CSMC2 and SMC2 cheeses (Figure 4), because concentrations of a portion of the citrate might have adsorbed to the $\mathrm{CN}$ during UF.

\section{pH and CLC}

Analyses of white crystals showed that total lactic acid ranged from 48.2 to $54.6 \%$ of the weight of crystals, confirming that the crystals observed were CLC. As the $\mathrm{pH}$ of the cheeses was reduced from 5.4 to 4.8 , an increased occurrence of CLC was observed in skim milk cheeses (Figure 5). The increased occurrence of CLC with the reduction in $\mathrm{pH}$ showed a positive relationship between increased SC and lactic acid in skim milk cheese. In SMC2, CLC were not observed in cheeses at $\mathrm{pH}$ 5.4, 5.3, and 5.2, but CLC were observed in cheeses at and below pH 5.1 (Figure 5). The intensity of CLC increased in cheeses with a decrease in $\mathrm{pH}$ to an extent that the cheese surfaces were covered with CLC at or below pH 5.1. Similarly, in CSMC2 and CSMC3, no CLC were observed in cheeses at $\mathrm{pH} 5.4$, but CLC were observed in cheeses at or below pH 5.3 (Figure 5). Again, the intensity of CLC increased in cheeses with a decrease in $\mathrm{pH}$, to an extent that entire cheese surfaces were covered with CLC at and below $\mathrm{pH}$ 5.3. As the $\mathrm{pH}$ of the cheese continues to decrease, more and more colloidal calcium becomes soluble and can combine with lactic acid to form CLC. The occurrence of CLC at low $\mathrm{pH}$ corroborates the results obtained by Swearingen et al. (2004) and Rajbhandari and Kindstedt (2005), which concluded that cheeses with the lowest $\mathrm{pH}$ and highest lactate concentrations within the first month of aging developed CLC. The $\mathrm{pH}$ of cheese is critical in the formation of CLC, because $\mathrm{pH}$ directly influences the amount of SC and lactic acid in the cheese serum.

\section{Protein Concentration and CLC}

Heavier occurrences of CLC were observed in cheeses made from CSM2 and CSM3 compared with those made from SM2. Calcium lactate crystals were observed in SMC2 in pH ranges of 5.1 to 4.8 , whereas CLC were observed at $\mathrm{pH} 5.3$ to 4.8 in CSMC2 and CSMC3. At equivalent $\mathrm{pH}, \mathrm{CLC}$ were observed with increased in- 


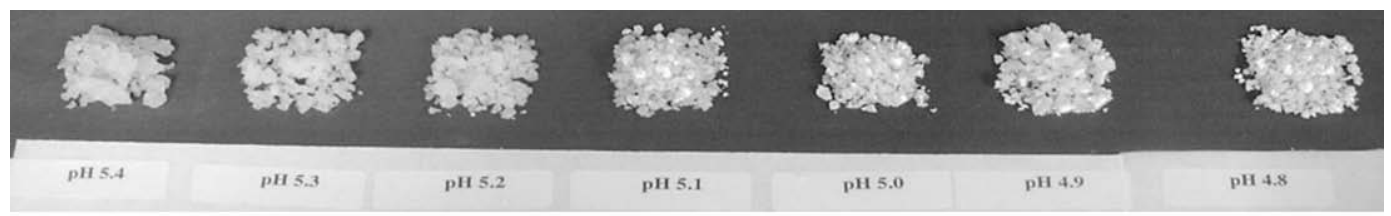

SMC2

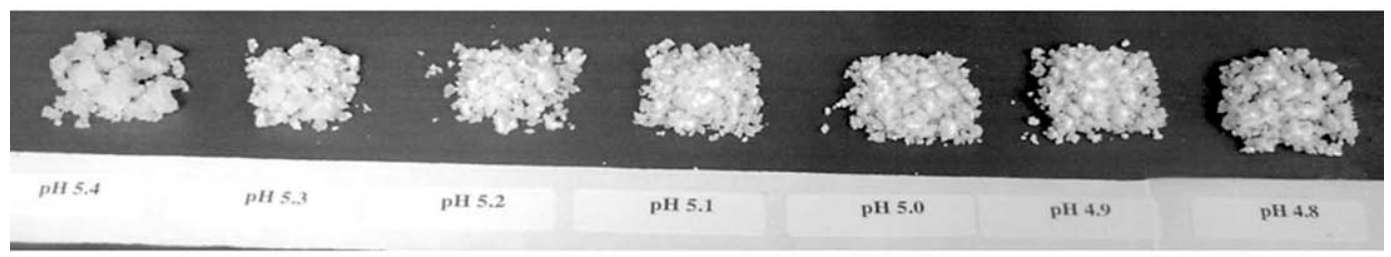

CSMC2

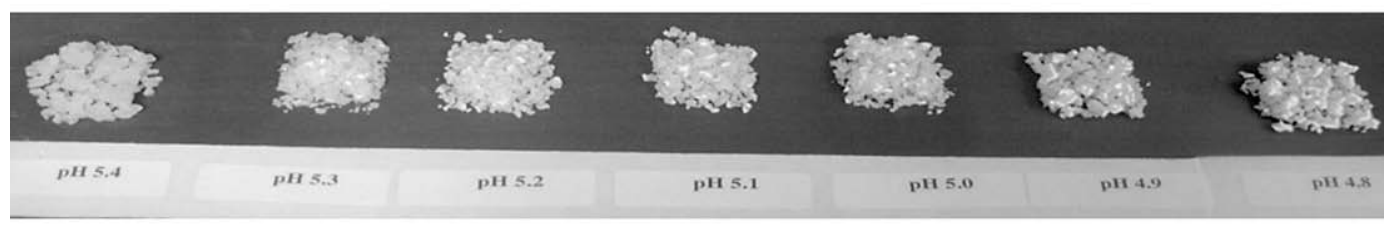

CSMC3

Figure 5. Calcium lactate crystals (bright white areas on the surface of cheese) in cheeses made from skim milk (SMC2), skim milk supplemented with UF milk (CSMC2), and skim milk supplemented with NDM (CSMC3) at pH 5.4 to 4.8.

tensity in cheeses manufactured with increased protein compared with cheeses made with smaller concentrations of protein. Total calcium in cheese is positively related to protein in cheese because calcium is structurally linked to CN (Lucey and Fox, 1993; Lee et al., 2005). With the increase in protein concentration, there was an increase in calcium, phosphate, and citrate concentrations in the cheese. Techniques such as UF, reverse osmosis, or addition of NDM to cheese milk to increase the protein concentration of cheese milk can lead to an increased occurrence of CLC in cheeses (Agarwal et al., 2005), even at $\mathrm{pH}$ ranges of 5.3 to 5.0. The calcium concentration in cheese is critical to CLC formation because as the $\mathrm{pH}$ of the cheese continues to decrease during aging, calcium becomes soluble and can combine with lactic acid to form CLC.

\section{DISCUSSION}

The objective of this research was to study the effect of protein concentration (3.14 and 6.80\%) and $\mathrm{pH}(5.4$ to 4.8 ) on the occurrence of CLC in Cheddar cheese while keeping other factors constant. Calcium lactate crystals were visible within a week in cheeses made from skim milk and concentrated milk having low $\mathrm{pH}$. A high correlation (0.67) was observed between the $\mathrm{pH}$ of the cheese and the occurrence of CLC. A positive correlation (0.82) was observed between lactic acid and $\mathrm{SC}$. As the $\mathrm{pH}$ of the cheese decreased, increased concentrations of SC were observed. The saturation limit of L(+)-lactate, as observed by Kubantseva et al. (2004), is $4.18 \mathrm{~g}$ of anhydrous calcium lactate at $10^{\circ} \mathrm{C}$ in 100 $\mathrm{g}$ of water at $\mathrm{pH} 5.00$. The amount of SC necessary to exceed the critical limit is $766.97 \mathrm{mg}$ in $100 \mathrm{~g}$ of water. In skim milk cheeses having 42 to $45 \%$ moisture, only 322 to $345 \mathrm{mg}$ of calcium is required to reach saturation, whereas in full-fat cheese having 36 to $38 \%$ moisture, only 276 to $291 \mathrm{mg}$ is required to reach saturation. The concentrations of SC in the experimental cheeses at all $\mathrm{pH}$ exceeded the theoretical saturation concentration of SC to form CLC, yet we did not see CLC in some of the cheeses. One possible reason for the absence of crystals in some of the cheeses is the reaction of part of the SC with soluble phosphates or citrates or both, and a subsequent reduction in the concentration of SC available to combine with lactate to form CLC. Most of the soluble phosphorus in milk and cheese exists in several forms of phosphates (Gaucheron, 2005; Upreti, and Metzger, 2006). In SMC2 at pH 5.1, CLC were observed (Figure 5). The cheese contained about 480 $\mathrm{mg}$ of SC and about $65 \mathrm{mg}$ of soluble phosphorus per $100 \mathrm{~g}$ of cheese (Table 3). We assumed that much of the calcium combined with phosphorus (present in the form of phosphate, $\mathrm{PO}_{4}{ }^{3-}$, equivalent to $\sim 2.1 \mathrm{mmol}$ ), 
to form calcium monohydrogen phosphate $\left(\mathrm{CaHPO}_{4}\right)$. Because $2.1 \mathrm{mmol}$ of phosphate will combine with 2.1 mmol of calcium, equivalent to $83.9 \mathrm{mg} / 100 \mathrm{~g}$ of cheese, $396.1 \mathrm{mg}$ of SC is available, which is higher than the theoretical saturation concentration of calcium (322 to $345 \mathrm{mg} / 100 \mathrm{~g}$ of cheese at 42 to $45 \%$ moisture) to form CLC (Figure 2). In CSMC2 at pH 5.4, no CLC were observed (Figure 5). The cheese contained about 432 $\mathrm{mg}$ of SC and about $92.5 \mathrm{mg}$ of soluble phosphorus per $100 \mathrm{~g}$ of cheese (Table 3). We assumed that much of the calcium combined with phosphorus (as described above), to form calcium monohydrogen phosphate. Because $3 \mathrm{mmol}$ of phosphate will combine with $3 \mathrm{mmol}$ of ionic calcium, equivalent to $120 \mathrm{mg} / 100 \mathrm{~g}$ of cheese, $312 \mathrm{mg}$ of SC remains to combine with lactate, which is less than the theoretical saturation concentration of calcium (322 to $345 \mathrm{mg} / 100 \mathrm{~g}$ of cheese at 42 to $45 \%$ moisture) to form CLC.

It is rare to identify a cheese manufacturer concentrating the cheese milk to $6.8 \%$ protein; most cheese manufacturers concentrate cheese milk to 3.8 to $5.0 \%$ protein to increase the throughput of their cheese plant. This research shows that increasing the protein concentration increases the risk of occurrence of CLC at low $\mathrm{pH}$. Follow-up research needs to be done with larger batches of cheeses using whole milk.

Crystal formation is influenced by lactate and calcium ions in the cheese serum. Additionally, the presence of nucleation sites inside or on the cheese or both, such as dead cells of microorganisms and crevices, promote the growth of crystals. Nucleation sites enable a smaller energy requirement for the development of crystals (Hartel, 2001). Also, CLC formation in cheese is influenced by other factors such as lactose concentration in cheese milk, starter bacteria, NSLAB, salt in moisture, storage temperature, and packaging (Johnson et al., 1990a; Johnson et al., 1990b; Chou et al., 2003; Swearingen et al., 2004; Agarwal et al., 2005; Blake et al., 2005; Agarwal et al., 2006). The abovementioned factors affect the concentration of SC and lactate in cheese. For instance, increased starter or NSLAB activity leads to low $\mathrm{pH}$, which leads to increased concentrations of SC and lactate. A low saltto-moisture ratio in cheese promotes the growth of starter and NSLAB bacteria. The solubility of calcium lactate is positively related to storage temperature (Chou et al., 2003; Kubantseva et al., 2004). Warmer storage temperatures increase the solubility of calcium lactate, whereas the solubility of calcium lactate decreases at colder temperatures (Kubantseva et al., 2004). Warmer storage temperatures promote increased starter and NSLAB activity (Agarwal et al., 2006), again leading to lower $\mathrm{pH}$. Loose packaging or packaging with poor barrier properties will promote surface drying of the cheese, increasing the concentrations of lactate and SC and leading to the formation of CLC (Agarwal, et al., 2005). Factors such as the lactose concentration in cheese milk, starter bacteria, NSLAB, salt-to-moisture ratio, storage temperature, and packaging promote the underlying reason why CLC occur, that is, a large concentration of SC and lactate in the cheese serum. Concentrating the cheese milk or making cheeses with low $\mathrm{pH}$ favors the occurrence of CLC in cheese even when few NSLAB are present in the cheese.

\section{CONCLUSIONS}

Protein concentrations in cheese milk and the $\mathrm{pH}$ of the cheese positively influenced the appearance of CLC on cheese. Concentrations of lactate and SC increased as the $\mathrm{pH}$ of the cheese decreased. Calcium lactate crystals were observed in skim milk cheeses at or below $\mathrm{pH}$ 5.1 and in cheeses made from concentrated skim milks at and below $\mathrm{pH}$ 5.3. The occurrence of calcium $\mathrm{L}(+)-$ lactate crystals in Cheddar cheese was enhanced by large protein concentrations in cheese milk and low postmanufacture $\mathrm{pH}$ of the cheese, which led to greater concentrations of calcium and lactate ions in the cheese serum. Cheese manufacturers can reduce the occurrence of CLC in cheeses by focusing on cheese-making techniques that reduce the concentration of TC and SC in the final cheese, which can be done by setting a low $\mathrm{pH}$ and introducing a curd-washing step.

\section{ACKNOWLEDGMENTS}

Appreciation is extended to Marc Evans for help provided in analyzing data using SAS. The authors appreciate the funding and support provided by the Washington State Dairy Products Commission (Lynnwood, WA).

\section{REFERENCES}

Agarwal, S., M. Costello, and S. Clark. 2005. Gas-flushed packaging contributes to calcium lactate crystals in Cheddar cheese. J. Dairy Sci. 88:3773-3783.

Agarwal, S., B. G. Swanson, G. U. Yuksel, and S. Clark. 2006. Nonstarter lactic acid bacteria biofilms and calcium lactate crystals in Cheddar cheese. J. Dairy Sci. 89:1452-1466.

Blake, A. J., J. R. Powers, L. O. Luedecke, and S. Clark. 2005. Enhanced lactose cheese-milk does not guarantee calcium lactate crystals in finished Cheddar cheese. J. Dairy Sci. 88:2302-2311.

Chou, Y. E., C. G. Edwards, L. O. Luedecke, M. P. Bates, and S. Clark. 2003. Nonstarter lactic acid bacteria and aging temperature affect calcium lactate crystallization in cheddar cheese. J. Dairy Sci. 86:2516-2524.

Dybing, S. T., S. A. Brudvig, J. A. Wiegand, and E. A. Huang. 1986. A simple method for estimating the extent of surface crystal development on colored Cheddar cheese. J. Food Prot. 49:421-422.

Dybing, S. T., J. A. Wiegand, S. A. Brudvig, E. A. Huang, and R. C. Chandan. 1988. Effect of processing variables on the formation of calcium lactate crystals on Cheddar cheese. J. Dairy Sci. 71:1701-1710. 
FDA (Food and Drug Administration). 2005. Skim milk cheese for manufacturing. Page 335 in Code of Federal Regulations. Title 21, Section 133.189. U.S. Government Printing Office, Pittsburgh, PA.

Feagan, J. T. 1956. A modification to the short method for Cheddar cheese manufacture. Aust. J. Dairy Technol. October-December:149-153.

Fox, P. F. 1993. Cheese: Chemistry, Physics and Microbiology. 2nd ed. Chapman \& Hall, London, UK.

Fox, P. F., and P. L. H. McSweeney. 2003. Advanced Dairy Chemistry. 3rd ed. Vol. 1. Kluwer Academic/Plenum, New York, NY.

Gaucheron, F. 2005. The minerals of milk. Reprod. Nutr. Dev. 45:473-483.

Hartel, R. W. 2001. Crystallization in Foods. Aspen Publishers, Gaithersburg, MD.

Hassan, A., M. E. Johnson, and J. A. Lucey. 2004. Changes in the proportions of soluble and insoluble calcium during the ripening of Cheddar cheese. J. Dairy Sci. 87:854-862.

Johnson, M. E. 2004. Calcium lactate crystals. Oral presentation at International Cheese Technology Exposition, Madison, WI.

Johnson, M. E., B. A. Riesterer, C. Chen, B. Tricomi, and N. F. Olson. 1990a. Effect of packaging and storage conditions on calcium lactate crystallization on the surface of Cheddar cheese. J. Dairy Sci. 73:3033-3041.

Johnson, M. E., B. A. Riesterer, and N. F. Olson. 1990b. Influence on nonstarter bacteria on calcium lactate crystallization on the surface of Cheddar cheese. J. Dairy Sci. 73:1145-1149.

Khalid, N. M., and E. H. Marth. 1990. Lactobacilli-Their enzymes and role in ripening and spoilage of cheese: A review. J. Dairy Sci. 73:2669-2684.

Kubantseva, N., R. W. Hartel, and P. A. Swearingen. 2004. Factors affecting solubility of calcium lactate in aqueous solutions. J. Dairy Sci. 87:863-867.

Kuehl, R. O. 2000. Design of Experiments: Statistical Principles of Research Design and Analysis. 2nd ed. Duxbury Press, Pacific Grove, CA.

Lee, M. R., M. E. Johnson, and J. A. Lucey. 2005. Impact of modifications in acid development on the insoluble calcium content and rheological properties of Cheddar cheese. J. Dairy Sci. 88:3798-3809.

Linke, W. F., ed. 1958. Solubilities of Inorganic and Metal Organic Compounds. 4th ed. Am. Chem. Soc., Washington, DC.

Lucey, J. A., and P. F. Fox. 1993. Importance of calcium and phosphate in cheese manufacture: A review. J. Dairy Sci. 76:1714-1724.

Marshall, R. T. 1992. Standard Methods for the Examination of Dairy Products. 16th ed. American Public Health Association, Washington, DC.

McDowall, F. H., and A. K. R. McDowell. 1939. The white particles in mature Cheddar cheese. J. Dairy Res. 10:118-119.

Metzger, L. E., D. M. Barbano, and P. S. Kindstedt. 2001. Effect of milk preacidification on low fat Mozzarella cheese. III. Post-melt chewiness and whiteness. J. Dairy Sci. 84:1357-1366.

Metzger, L. E., D. M. Barbano, M. A. Rudan, and P. S. Kindstedt. 2000. Effect of milk preacidification on low fat Mozzarella cheese. I. Composition and yield. J. Dairy Sci. 83:648-658.

Pearce, K. N., L. K. Creamer, and J. Gilles. 1973. Calcium lactate deposits on rindless Cheddar cheese. N. Z. J. Dairy Sci. Technol. 8:3-7.

Pollman, R. M. 1991. Atomic absorption spectrophotometric determination of calcium and magnesium and colorimetric determination of phosphorus in cheese: Collaborative study. J. AOAC 74:27-31.

Rajbhandari, P., and P. S. Kindstedt. 2005. Compositional factors associated with calcium lactate crystallization in smoked Cheddar cheese. J. Dairy Sci. 88:3737-3744.

SAS Institute. 2005. SAS User's Guide. Version 9.1. SAS Inst., Inc., Cary, NC.

Somers, E. B., M. E. Johnson, and A. C. L. Wong. 2001. Biofilm formation and contamination of cheese by nonstarter lactic acid bacteria in the dairy environment. J. Dairy Sci. 84:1926-1936.

Swearingen, P. A., D. E. Adams, and T. L. Lensmire. 2004. Factors affecting calcium lactate and liquid expulsion defects in Cheddar cheese. J. Dairy Sci. 87:574-582.

Upreti, P., and L. E. Metzger. 2006. Influence of calcium and phosphorus, lactose, and salt-to-moisture ratio on Cheddar cheese quality: Manufacture and composition. J. Dairy Sci. 89:420-428. 